Jason Radine

\title{
The Book of Amos in Emergent Judah
}

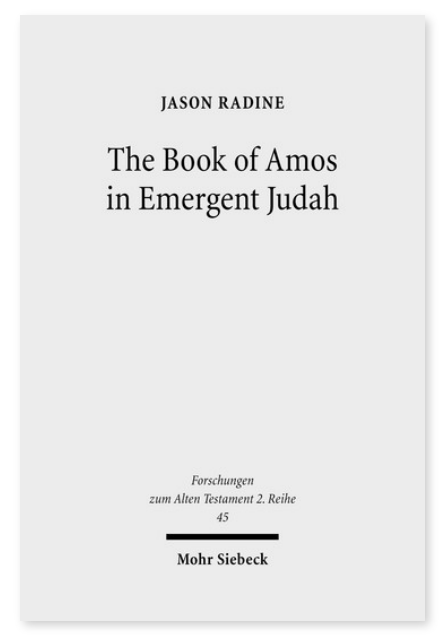

2010. XII, 270 Seiten. FAT II 45

ISBN 978-3-16-151143-1

DOI 10.1628/978-3-16-151143-1

eBook PDF $74,00 €$

ISBN 978-3-16-150114-2

fadengeheftete Broschur 74,00€
[Das Buch Amos im aufstrebenden Juda.]

Veröffentlicht auf Englisch.

Die neuere Forschung zur Prophetenliteratur im Nahen Osten sowie neue archäologische Modelle zur Entwicklung des antiken Juda und Israel haben große Auswirkungen auf das Studium der biblischen Prophetenliteratur. Jason Radine erarbeitet vor dem Hintergrund dieser neuen Einsichten eine Neubewertung des Buches Amos. Er zeigt, dass die biblische Prophetenliteratur völlig anders zu bewerten ist als die Quellen für Prophetie im Alten Orient und im antiken Israel. Das Buch Amos ist - so der Autor - kein »Prophetenbuch« im Sinne der Tradition des Alten Orients, sondern vielmehr ein religiöspolitisch motiviertes Dokument, das den Rückzug der göttlichen Gunst aus den nördlichen Regionen erklärt und rechtfertigt. So verwendet der Autor des Buches Amos zum Beispiel einerseits Klage-Rhetorik, um die Eroberung Israels durch die Assyrer zu beschreiben, rechtfertigt aber andererseits die Zerstörung des nördlichen Königreiches, indem er die dort herrschende soziale Ungerechtigkeit anprangert.

Jason Radine Born 1972; 1994 BA, University of Michigan (Philosophy); 1999 MA, and 2007 PhD, University of Michigan (Near Eastern Studies, specializing in Ancient Israel/Hebrew Bible); Assistant Professor of Biblical and Jewish Studies, Department of Religion, Moravian College, Bethlehem, PA., USA.
Jetzt bestellen:

https://mohrsiebeck.com/buch/the-book-of-amos-in-emergent-judah-9783161511431?no_cache=1

order@mohrsiebeck.com

Telefon: +49 (0)7071-923-17

Telefax: +49 (0)7071-51104 